\title{
TERBITNYA SERTIFIKAT HAK ATAS TANAH AKIBAT PERALIHAN HAK YANG CACAT HUKUM
}

\author{
Tri Susilaningsih \\ Fakultas Hukum Universitas Merdeka Malang \\ JI. Terusan Dieng No. 62-64; Malang; 65146; Indonesia; (0341) 580161 \\ trisusilaningsih25@gmail.com
}

\begin{abstract}
The transfer of land rights is a process of transferring the right of ownership of one person lawfully and to the ownership of the new person forever as long as the rights are not transferred. Authentic deeds are the basis or evidence of such transfer of rights made by the land deed. The registration of the transfer of rights is a means of obtaining legal protection from the controlled land. The principle of land registration should reflect a thoroughness of ownership of the land and the rights of third parties affecting it. The transfer of rights as stated in the provisions of Government Regulation No. 10/1961 on Land Registration and Government Regulation No. 24/1997 on Land Registration. Submission by this Deed means that the ownership of the land has been transferred from the old owners of the new ownership and the new owner is obliged to register his land rights in the National Land Agency to obtain legal certainty and legal protection. The proof of ownership is a Certificate. There are times when the issuance of Certificates is due to the transfer of a right or legal disability ground.
\end{abstract}

Keywords:Certificate, Land Registration, Transfer of Land Right.

\begin{abstract}
Abstrak
Peralihan hak atas tanah adalah suatu proses pengalihan hak kepemilikan dari satu orang lainya yang sah menurut hukum dan menjadi kepemilikan orang baru tersebut selamanya sepanjang tidak dialihkan kembali hak tersebut. Akta autentik merupakan dasar atau bukti dari peralihan hak tersebut yang dibuat oleh pejabat pembuat akta tanah. Pendaftaran peralihan hak ini merupakan suatu cara untuk mendapatkan perlindungan hukum dari tanah yang dikuasai.Prinsip pendaftaran tanah harus mencerminkan suatu ketelitian mengenai kepemilikan dari tanah dan hak hak pihak ketiga yang mempengaruhinya. Peralihan haktertera dalam ketentuan Peraturan Pemerintah Republik IndonesiaNomor 10 Tahun 1961 tentang Pendaftaran Tanah dan Peraturan Pemerintah Republik Indonesia Nomor 24 Tahun 1997 tentang Pendaftaran Tanah. Penyerahan dengan Akta ini berarti kepemilikan tanah sudah beralih dari pemilik lama kepemilik baru dan pemilik baru wajib untuk mendaftarkan hak atas tanahnya di Badan Pertanahan Nasional guna mendapatkan kepastian hukum dan perlindungan hukum. Bukti kepemilikannya berupa Sertifikat. Ada kalanya penerbitan Sertifikat terjadi akibat peralihan hak ata tanah cacat hukum.
\end{abstract}

Kata kunci:Pendaftaran Tanah,Peralihan Hak Atas Tanah, Sertifikat. 
Peralihan hak atas tanah itu menyebabkan hak atas tanah beralih dari satu orang kepada orang lain. Peralihan hak adalah perbuatan hukum yang sengaja dilakukan dengan tujuan agar hak atas tanah berpindah dari yang mengalihan kepada yang menerima pengalihan (Perangin, 1991). Adapun yang termasuk peralihan hak tersebut adalah jual beli tanah, penghibahan tanah, pewarisan tanah dan perwakafan tanah.

Pasal 19 Peraturan Pemerintah Republik Indonesia Nomor 10 Tahun 1961 tentang Pendaftaran Tanah yang kemudian disempurnakan dengan Peraturan Pemerintah Republik Indonesia Nomor 24 Tahun 1997 tentang Pendaftaran Tanah, khususnya Pasal 37 mengatur tentang peralihan hak tanah harus dilakukan dengan akta autentik. Pasal 19 Peraturan Pemerintah Republik Indonesia Nomor 10 Tahun 1961 berbunyi,setiap perjanjian yang berkaitan dengan peralihan hak atas kepemilikan tanah harus dilakukan di depan pejabat yang di tunjuk Menteri Agraria. Sedangkan Pasal 37 Peraturan Pemerintah Republik Indonesia Nomor 24 Tahun 1997 menyatakan bahwa peralihan hak atas tanah dapat dilakukan dengan mendaftarkan kepada Pejabat Pembuat Tanah (PPAT) yang mempunyai wewenang menurut undang-undang (Harmon, 2010). Peraturan tersebut diatas merupakan peraturan pelaksana dari Undang-Undang Republik Indonesia Nomor 5 Tahun 1960 tentang Pokok Dasar Agraria (UU PA).

Pendaftaran peralihan hak ini mendapatkan kepastian dan perlindungan hukum terhadap tanah yang dimiliki. Sebagai bukti pendaftaranz peralihan hak ini adalah Sertifikat. Menurut Pasal 32 Ayat (1) Peraturan Pemerintah Republik Indonesia Nomor 24 Tahun 1997 menyebutkan, bahwa sertifikat merupakan suatu alat bukti kepemilikan atas tanah dibuat berdasarkan data yang benar dengan data fisik dan data yuridis (Harmon, 2010). Ada kalanya penerbitan setipikat hak atas tanah akibat peralihan hak cacat hukum.
Permasalahanmendasar dalam hubungan ini adalah sertifikat hak atas tanah yang mengalami cacat menurut hukum bagamana akibat hukum dari terbitnya surat tersebut.

\section{Macam Peralihan Hak Atas Tanah dan Pendaftarannya}

\section{Pandangan Hukum Adat dan UU PA terhadap Jual Beli}

Jual beli menurut hukum adat adalah suatu perbuatan dimana perbuatan itu membawa akibat perpindahan hak atas tanah sesuai dengan sifat terang, riil dan tunai. Oleh karena itu hal ini berarti bahwa setiap pemindahan hak atas tanah harus dilakukan di depan kepala adat yang berperan sebagai pejabat yang bersaksi sebagai pembenar bahwa telah terjadi peralihan hak kepemilikan tanah dari orang satu ke orang lain sehingga perbuatan tersebut diketahui masyarakat luas (Sutedi, 2007).

Apabila terjadi pembeli tidak mampu memberikan sejumlah uang berdasarkan kesepakatan harus dibayar untuk ganti peralihan hak kepadanya tidak terlaksana maka atas dasar hal tersebut akan menjadi utang piutang. Putusan Mahkamah Agung Nomor 271/K/Sip/1956 dan Nomor 840/K/Sip/ 1971 mengatakan suatu suatu jual beli harus riil, artinya bahwa dengan melakukan ucapan jual beli melalui percakapan maka terjadilah jual beli. Walaupun tanah masih berada dipengawasan penjual ketikatelah terjadi penulisan kontrak jual beli di depan kepala desa serta menerima harganya maka kontrak tersebut sah secara hukum (Sutedi,2007).

UU PA tidak diatur secara jelas tentang jual beli tanah, hukum tanah yang belaku nasional tidak mengatur secara tegas hukum tanah kita, dalam Pasal 5 UU PA menyebutkan hukum tanah berdasarkan hukum adat. Hal ini berarti bahwa hukum adat diberlakukan untuk mengatur sistem hukum pertanahan. Pengertian jual beli tanah menurut 
hukum adat berarti bahwa sistem hukum adat digunakan untuk mengisi kekosongan hukum pertanahan dihilangkan sifat kedaerahannya dan diberikan sifat untuk mengatur secara nasional (Harmon, 2010).

Sejak berlakunya Peraturan Pemerintah Republik Indonesia Nomor 10 Tahun 1961 tentang Pendaftaran Tanah, jual beli yang dilakukan oleh kedua belah pihak dihadapan PPAT yang bertugas membuat akta. Dengan dilakukannya jual beli di hadapan PPAT, berarti sifat terang telah terpenuhi. Akta jual beli yang telah ditanda tangani oleh para pihak tersebut, berarti telah terjadi peralihan hak atas tanah dari penjual kepada pembeli yang disertai dengan pembayaran harga tanah. Berarti telah terpenuhi sifat tunai dari jual beli tersebut dan menunjukkan sifat riil/ nyata perbuatan hukum jual beli yang bersangkutan telah dilaksanakan.

Perlu diketahui adanya syarat jual beli, yaitu syarat materiil dan syarat formal. Syarat-syarat tersebut adalah

a. Syarat Materiil, merupakan syarat yang menentukan sahnya jual beli tanah tersebut, antara lain:

1. Pembeli berhak membeli tanah yang bersangkutan. Pembeli sebagai penerima hak harus memenuhi syarat untuk memiliki tanah yang akan dibelinya. Untuk menentukan berhak tidaknya sipembeli memperolh hak atas tanah yang dibelinya tergantung pada apa yang ada pada tanah tersebut, apakah hak milik (HM), Hak Guna Bangunan (HGB) atau hak pakai (HP).

2. Penjual barhak menjual tanah yang bersangkutan.

Yang berhak menjual tanah yang bersangkutan adalah pemilik. Pemilik, adalah orang yang berhak atas tanah tersebut/ pemegang hak yang sah atas tanah ysang bersangkutan. Apabila pemilik tanah hanya seorang, maka yang berhak menjual adalahn dia sendiri. Apabila pemilik tanah adalah dua orang, maka yang berhak menjual adalah kedua orang tersebut secara bersama-sama. Tidak boleh seorang saja yang bertindak sebagai penjual (Parangin, 1994).

3. Tanah hak yang bersangkutan boleh diperjual belikan dan tidak sedang dalam sengketa. Menurut UU PA hak atas tanah yang boleh diperjual belikan adalah Hak Milik, Hak Guna Usaha, Hak Guna Bangunan dan hak Pakai. Jika salah satu syarat materiil ini tidak dipenuhi, dalam arti penjual bukan merupakan orang yang berhak atas tanah yang dijualnya atau pembeli tidak memenuhi syarat untuk menjadi pemilik hak atas tanah yang diperjual belikan sedang dalam sengketa atau merupakan tanah yang tidak boleh diperjual belikan, maka jual beli tanah tersebut tidak sah. Jual beli tanah yang dilakukan oleh yang tidak berhak adalah batal demi hukum. Artinya sejak semula hukum menganggap tidak pernah terjadi jual beli (Sutedi, 2005).

b. Syarat Formal.

Setelah semua syarat materiil dipenuhi, maka PPAT akan membuatkan Akta jual belinya. Jual beli tanah yang tidak dilakukan di hadapan PPAT tetap sah karena UU PA berlandaskan Hukum Adat (Pasal 5 UU PA) sedangkan dalam hukum adat yang dipakai adalah sistim yang konkrit/nyata/riil. Untuk mewujudkan adanya kepastian hukum dalam setiap peralihan hak atas tanah, Peraturan Pemerintah Republik Indonesia Nomor 24Tahun 1997 sebagai Peraturan Pelaksanaan dari UU PA menentukan bahwa setiap perjanjian yang bermaksud memindahkan hak atas tanah harus dibuktikan dengan sebuah akta yang di buat oleh dan di hadapan PPAT (Effendi, 1993). 


\section{Penghibahan Hak Atas Tanah}

Pengaturan hibah diatur dalam Pasal 1666 KUHPerdata dimana hibah merupakan suatu perbuatan memberikan barang sesuatu tanpa imbalan dan dengan keadaan bebas tanpa unsur paksaan dilakukan untuk tidak ditarik kembali untuk memberikan suatu benda kepada penerima hibahsesudah pewasiat wafat (Sutedi, 2007).

Akta hibah merupakan suatu tindakan pendaftaran hak atas tanah kepada PPAT untuk mendapatkan akta autentik bukti pemilikan atas tanah diatur di Peraturan Pemerintah Republik Indonesia Nomor 24 Tahun 1977 tentang Pendaftaran Tanah. Pasal 1682, 1867 dan Pasal 1869 BW menyatakan bahwa akta hibah memiliki fungsi autentik nantinya dapat digunakan untuk pembuktian kepemilikan hak atas tanah.

Kekuatan autentik sebagai alat pembuktian diharuskan memiliki tanda tangan kedua belah pihak setelah sebelumnya dibuat bersama atas dasar kesepakatan oleh pihak-pihak yang berwenang serta para pihak yang terkait. Peraturan Pemerintah Republik Indonesia Nomor 10 Tahun1961 menentukan PPAT harus membuat akta hibah untuk obyek hibah yang diajukan. Obyek hibah apabila merupakan benda bergerak menurut KUHPerdata maka dasar pembuatan akta dibuat dan ditanda tangani oleh notaries (Sutedi, 2007).

Menurut Sutedi Adrian, bahwa ada beberapa syarat bisa mengakibatkan batalnya suatu akta yang dibuat untuk hibah sebagaimana diatur di ketentuan Pasal 1688 KUH Perdata, sebagai berikut:

a. Karena tidak dipenuhi syarat-syarat dengan mana penghibahan telah dilakukan.

b. Jika sipenerima hibah telah bersalah melakukan atau membantu melakukan kejahatan yang bertujuan mengambil jiwa si penghibah atau suatu kejahatan lain terhadap si penghibah.

c. Jika ia menolak memberikan tunjangan nafkah kepada si penghibah, setelah orang ini jatuh dalam kemiskinan. d. Adanya unsur perbuatan melawan hukum dalam hal penghibahan dapat pula membatalkan akta hibah.

\section{Pewarisan Tanah}

Peralihan hak atas terhadap seseorang dapat terjadi karena pewarisan sebagaimana yang diatur dalam Pasal 26 UUPA.Pewarisan terjadi ketika seorang pemilik hak tanah pertama meninggal maka secara otomatis terjadi peralihan hak atas tanah kepada ahli warisnya secara bersama. Apabila ahli waris sudah mendapatkan pembagian waris berdasarkan surat keterangan waris dari pewaris maka hal tersebut peralihan hak atas tanah langsung berpindah apabila pewaris wafat. Pendaftaran tanah dari ahli waris sangat memerlukan surat keterangan waris untuk dapat memindahkan hak milik kepada ahli waris (Sutedi,2007).

Peralihan hak atas waris menurut Pasal 42 Peraturan Pemerintah Republik Indonesia Nomor 24 Tahun 1997, sebagai berikut:

a. Hak terdaftar, peralihan hak wajib diserahkan kepada Kantor Pertanahan, Sertifikat yang bersangkutan, Surat Kematian orang yang namanya dicatat sebagai pemegang haknya dengan surat tanda bukti sebagai ahli waris. Peralihan hak karena pewarisan terjadi karena hukum pada saat yang bersangkutan meninggal dunia. Dalam arti, bahwa sejak itu para ahli waris menjadi pemegang hak yang baru. Pendaftaran peralihan hak karena pewarisan juga diwajibkan dalam rangka memberikan perlindungan hukum kepada para ahli waris dan demi ketertiban tata usaha pendaftaran tanah. Surat tanda bukti sebagai ahli waris dapat berupa Akta Keterangan Hak Mewaris, atau Surat Penetapan Ahli Waris atau Surat Keterangan Ahli Waris.

b. Tanah sebagai waris belum terdaftar, diserahkan dokumen-dokumen surat keterangan Kepala Desa/ Lurah yang menyatakan, bahwa yang bersangkutan menguasai tanah, dan 


\section{Jurnal Cakrawala Hukum}

Vol.8, No.1 Juni 2017: 118-128

surat keterangan yang menyatakan, bahwa bidang tanah tersebut belum bersertifikat dari Kantor Pertanahan, atau surat keterangan Kepala Desa jika lokasi tanahnya jauh dari kedudukan Kantor Pertanahan dari pemegang hak yang bersangkutan. Dokumen yang membuktikan adanya hak atas tanah pada yang mewariskan diperlukan karena pendaftaran peralihan hak ini baru dapat dilakukan setelah pendaftaran untuk pertama kali atas nama pewaris.

c. Penerima tunggal, pendaftaran peralihan hak tersebut dilakukan kepada orang tersebut berdasarkan surat tanda bukti sebagai ahli waris seperti tersebut pada angka 1 di atas.

d. Terdiri dari beberapa penerima waris, hak tersebut didaftarkan disertai dengan akta pembagian waris yang memuat keterangan, bahwa hak atas tanah jatuh kepada seorang penerima warisan tertentu, pendaftaran hak milik atas tanah dilakukan kepada penerima warisan yang bersangkutan berdasarkan suatu tanda bukti sebagai ahli waris dan akta pembagian waris tersebut.

e. Warisan berupa hak atas tanah yang menurut akta pembagian waris harus dibagi bersana antara beberapa penerima warisan atau waktu di daftarkan belum ada akta pembagian warisnya, didaftar peralihan haknya kepada para penerima waris yang berhak sebagai hak bersama mereka berdasarkan surat tanda bukti sebagai ahli waris dan/ atau akta pembagian waris tersebut.

Hak peralihan waris bersama setelah mendapatkan kesepakatan berdasarkan Pasal 51, pembagaian hak atas tanah dilakukan berdasarkan surat keterangan wasiat dan dibuat dihadapan PPAT yang memiliki wewenang sebagai pembenar kesepakatan antara pihak-pihak berkepentingan waris tersebut. Pembagian waris tidak selamanya sesuai dengan surat keterangan wasiat, atas dasar kesepakatan bersama penerima waris dapat mengalihkan waris kepada individu tunggal atau pihak lain sesuai kesepakatan bersama pemegang hak (Sutedi, 2007).

\section{Perwakafan Tanah}

Suatu perbuatan untuk tidak menaruh benda di tempat tansaksi dan diberikan untuk dimanfaatkan orang lain dan dijalankan dengan tujuan tertentu boleh digunakan dan menghasilakan manfaat bagi masyarakat luas adalah suatu pengertian dari wakaf menurut Anwar (1992). Sedangkan, pengertianwakaf menurut Muhammad Yamin Lubis dan Abdul Rahim Lubis(2012),suatu tindakan memisahkan dan menyerahkan sebagian harta sesuai keinginannya untuk diberikan kepada orang lain untuk kepentingan tertentu bermanfaat dalam jangaka waktu lama guna kepentingan agama atau untuk kesejahteraan umum menurut syariah.

Pasal 49 UU PA tentang wakaf menjelaskan bahwa:

1. Hak milik tanah badan-badan keagamaan dan sosial sepanjang dipergunakan untuk usaha dalam bidang keagamaan dan sosial, diakui dan dilindungi. Badan tersebut dijamin pula akan memperoleh tanah yang cukup untuk bangunan dan usahanya dalam bidang keagamaan dan sosial.

2. Untuk keperluan peribadatan dan keperluan suci lainnya sebagaimana dimaksud Pasal 14 dapat diberikan tanah yang dikuasai langsung oleh Negara dengan Hak Pakai.

3. Perwakafan tanah milik dilindungi dan diatur dengan Peraturan Pemerintah.

Perwakafan, apabila ada sebidan tanah yang hendak di wakafkan sebaiknya terhindar dari kedudukan khusus atau kegiatan transaksi (jual beli, sewa-beli, hibah, waris, penjaminan, dan bentuk pengalihan lainnya). Ketika sebidang tanah sudah diwakafkan maka akibatnya sebidang tanah ter- 
sebut dianggap sebagai subyek hukum. Oleh karena itu, tanah wakaf ini mendapatkan jaminan terhadap kegiatan transaksional.

Wakaf agar mempunyai kepastian hukum atas tanah wakaf diperlukan ikrar wakaf dengan suatu akta oleh Kepala Kantor Urusan Agama (KUA) sebagai pejabat pembuat Akta Ikrar Wakaf (PPAIW) dan akta ini dianggap sah jika dihadiri dan disaksikan sekurang-kurangnya 2 orang saksi, yang disertai dengan surat-surat bukti pemilikan tanah, surat keterangan Kepala Desa, Surat Keterangan Pendaftaran. Setelah Akta Ikrar Wakaf dibuat selanjutnya dilakukan pendaftaran wakaf tanah milik ke Kantor Pertanahan Kab/Kota untuk memperoleh sertifikat (Sutedi, 2007).

Pasal 3 Peraturan Pemerintah Republik Indonesia Nomor 24 Tahun 1997 mengatur tentang tujuan dari pendaftaran tanah, dijelaskan sebagai berikut:

a. Untuk memberikan kepastian hukum dan perlindungan hukum kepada pemegang hak atas suatu bidang tanah, satuan rumah susun dan hak-hak lain yang terdaftar agar dengan mudah dapat membuktikan dirinya sebagai pemegang hak yang bersangkutan.

b. Menyediakan Informasi kepada pihak-pihak yang berkepentingan termasuk Pemerintah agar dengan mudah dapat memperoleh data yang diperlukan dalammengadakan perbuatan hukum mengenai bidang bidang tanah dan satuan satuan rumah susun yang sudah terdaftar.

c. Untuk terselenggaranya tertib administrasi pertanahan.

Menurut Pasal 19 UUPA, pemerintah berkewajiban menyelenggarakan pendaftaran tanah. Upaya pendaftaran tanah digunakan untuk mengatur, penguasaan pemilikan dan penggunaan tanah serta dapat mengatasi berbagai permasalahan tanah kedepan. Pendaftaran tanah nantinya diberikan sertifikat tanah sebagai bukti kepemilikan atas tanah dan digunakan memberikan perlindungan hukum kepada pemegang hak atas tanah. Pendaftaran hak-hak atas tanah merupakan jaminan dari Negara, dan merupakan suatu instrument penting untuk perlindungan pemilik tanah. Pendaftaran tanah bersifat recht kadaster yang meliputi kegiatan 1) pengukuran, pemetaan,dan pembukuan tanah; 2) pendaftaran hak hak tersebut; 3) pemberian sertifikat hak atas tanah sebagai alat pembuktian yang kuat(Sutedi, 2012).

Menurut A. P. Parlindungan (1999),Pasal 19 UU PAsebagai dasar lahirnya peraturan yang mengatur pendaftarn tanah, peraturan tersebut berbunyi sebagai berikut:

1. Menjamin kepastian hukum oleh Pemerintah diadakan Pendaftaran Tanah di seluruh wilayah Republik Indonesia menurut ketentuanketentuan yang diatur dengan Peraturan Pemerintah.

2. Pendaftaran tanah tersebut dalam ayat (1) Pasal ini meliputi:

a. Pengukuran, perpetaan dan Pembukuan tanah.

b. Pendaftaran hak-hak atas tanah dan peralihan hak-hak atas tanah tersebut.

c. Pemberian surat-surat tanda bukti-bukti yang berlaku sebagai alat pembuktian yang kuat.

3. Pendaftaran tanah diselenggarakan dengan mengingat keadaan Negara dan masyarakat, keperluan lalu-lintas sosial-ekonomi serta kemungkinan penyelenggaraannya, menurut pertimbangan Menteri Agraria.

4. Peraturan Pemerintah diatur biaya-biaya yang bersangkutan dengan pendaftaran termaksud dalam ayat (1) diatas dengan ketentuan bahwa rakyat yang tidak mampu dibebaskan dari pembayaran biaya-biaya tersebut.

Tujuan utama dari pendaftaran tanah adalam memberikan jaminan hukum dan perlindungan hukum kepada pemegang hak atas tanah, misalnya 
pembeli akan menikmati tanah dengan tidak ada gangguan dari pihak lain. Selain itu pendaftaran tanah dibuat untuk menemukan apakah ada hakhak pihak ketiga. Pokok gagasan dalam sistem pendaftaran tanah adalah: mencatat hak-hak atas tanah, kemudian menggantikan bukti kepemilikan atas pemberian hak atas tanahnya.

Prinsip pendaftaran tanah harus mencerminkan suatu ketelitian mengenai kepemilikan dari tanah dan hak hak pihak ketiga yang mempengaruhinya. Prinsip jaminan pendaftaran tanah adalah status hak memberikan jaminan dari ketelitian suatu daftar, bahkan seharusnya memberikan ganti kerugian kepada siapapun yang menderita kerugian (Daliyo dkk., 2001).

Faktor aman sebagai salah satu asas dan tujuan pendaftaran tanah haruslah diartikan oleh Badan Pertanahan Nasional sebagai keharusan berhati-hati, cermat dan teliti dalam memproses penerbitan Sertifikat tanah dan pekerjaan pendaftaran tanah agar tercapai kebenaran mengenai siapa pemilik tanahnya dan apa yang menjadi obyek miliknya mengenai luas, batas dan lokasi yang disebutkan dalam isi sertifikat. Rasa aman agar hasil proses pendaftaran tanah dan mendapatkan sertifikat mendapatkan kepastian dan perlindungan hukum kepada pemegang hak atas tanahnya.

\section{Sertifikat Wujud Bukti Hak Milik Atas Tanah}

Kepemillikan sertifikat tanah didapat setelah mendaftarkan hak atas tanah dan hak atas tanah beralih kepada seseorang. Atas permohonan pemilik hak atas tanah selanjutnya berdasarkan bukti data fisik dan data yuridis dapat mengajukan permohonan untuk didaftar dalam buku tanah dan mendapatkan sertifikat sebagaimana dalam ketentuan Pasal 30 Ayat (1) Peraturan Pemerintah Republik Indonesia Nomor 24 Tahun 1997 (Harmon, 2010).

Data fisik adalah keterangan mengenai letak, batas dan luas bidang tanah dan satuan rumah susun yang didaftar, termasuk keterangan mengenai adanya bangunan atau bagian bangunan diatasnya (Pasal 1 PP No.24 Tahun 1997 tentang Pendaftaran Tanah) (Harmon, 2010). Data yuridis adalah keterangan mengenai status hukum bidang tanah dan satuan rumah susun yang didaftar, pemegang haknya dan hak pihak lain serta beban beban lain yang membebaninya (Pasal 1 angka 7 PP No.24 Tahun 1997 tentang Pendaftaran Tanah. Memperoleh sertifikat adalah hak pemegang hak atas tanah yang dijamin Undang-Undang (Harmon, 2010).

Menurut Pasal 13 Peraturan Pemerintah Republik Indonesia Nomor 10 Tahun 1961 jo Pasal 19 UU PA bahwa sertifikat diberikan kepada yang berhak. Sertifikat adalah surat tanda bukti hak, yang merupakan alat pembuktian yang kuat, baik mengenai macam hak, subyek maupun tanahnya.

Penerbitan sertifikat tanah merupakan kebutuhan utama pemilik tanah saat ini untuk diterbitkan dengan cepat dan biaya murah. Kehendak pemilik tanah dapat dimaklumi, karena peraturan pendaftaran tanah memang sudah mengamanatkan kepada Badan Pertanahan Nasional (BPN) untuk mengurusi pendaftaran tanah. Penerbitan sertifikat tanah harus disesuaikan dengan asas sederhana dan terjangkau, dimana asas-asas tersebut mengamanatkan proses penerbitan sertifikat tanah berjalan dalam waktu cepat, sedangkan untuk biayanya penerbitan sertifikat tanah tidak terlalu mahal terjangkau oleh golongan orang tidak mampu.

Menurut Effendi Perangin (1991), bahwa salinan buku tanah dan surat ukur setelah dijilid menjadi satu bersama sama dengan suatu kertas sampul yang bentuknya ditetapkan dengan peraturan disebut sertifikat. Sedangkan menurut M. Yamin Lubis dan Abd.Rahim Lubis (2012), kalau dikatakan sertifikat tanah adalah surat keterangan yang membuktikan hak seseorang atas sebidang tanah, atau ada seseorang yang memiliki bidang bidang tanah tertentu dan pemilikan itu mempunyai bukti yang kuat berupa surat yang dibuat oleh instansi yang berwenang inilah yang disebut sertifikat tanah. 
Sertifikatdigunakan sebagai suatu bukti untuk menyatakan bahwa tanah ini telah diadministrasi oleh Negara. Bukti atau sertifikat itu adalah milik seseorang yang sesuai dengan yang tertera dalam sertifikat tersebut.Bagi sipemilik tanah, sertifikat tadi adalah merupakan pemegang hak yang kuat dalam hal pembuktian hak miliknya, sebab dikeluarkan oleh Instansi yang ah dan berwenang secara hukum. Apalagi namanya yang tersebut dalam sertifikat pasti akan dilindungi oleh hukum. Sehingga apabila yang memegang sertifikat itu belum namanya, maka perlu dilakukan balik namanya kepada yang memegangnya sehingga terhindar dari gangguan pihak lain.

Sertifikat tanah sebagai bukti digunakan lebih banyak berhubungan dengan esensi kepentingan dan manfaatnya yang dapat disewakan, diperjual belikan, dikerjasamakan dan dijadikan tanggungan. Berarti semua kepentingan tersebut akan di administrasikan dan diberikan perlindungan hukum jika suatu ketika akan muncul kasus kasus dalam tanah tersebut.

Pendaftaran tanah akan menciptakan keuntungan akibat pelaksanaan administrasi pertanahan yang sah, yaituMemberikan jaminan keamanan penggunaan bagi pemiliknya; Mendorong atau meningkatkan penarikan pajak oleh Negara; Meningkatkan fungsi tanah sebagai jaminan kredit; Meningkatkan pengawasan pasar tanah; Melindungi tanah Negara; Mengurangi sengketa tanah; Memfasilitasi kegiatan rural land reform; Meningkatkan urban planning dan memajukan infrastruktur; Mendorong pengelolaan lingkungan hidup yang berkualitas; Menyediakan data statistik tanah yang baik (Lubis\&Abdul 2012).

\section{Masalah Penerbitan Sertifikat Hak Atas Tanah}

Menurut Putusan MA No.350K/Sip/1068 bahwa pada prinsipnya jual beli terjadi ketika suatu benda berpindah hak dari orang satu ke orang lain berdasarkan undang-undang secara yuridis.Pasal
26 UU PA, peralihan hak milik dilakukan apabila pembelinya adalah WNI. Jadi kalau WNA tidak bisa membeli tanah dengan hak milik, berarti tidak akan ada peralihan hak atas tanah.Peraturan Pemerintah Republik Indonesia Nomor 10 Tahun 1961 menyatakan bahwa jual beli dilakukan para pihak di hadapan PPAT. Dengan demikian jual belinya bersifat terang karena telah diketahui Kepala Desa/ Kepala Kampung/ Kepala Adat dan Kepala Desa dianggap yang paling tahu secara hukum tentang tanah yang dijadikan obyek jual beli.

Apabila para pihak yang menanda tangani Akta PPAT tersebut berarti telah terjadi peralihan hak dan ini telah membuktikan telah terjadi peralihan dari penjual (pemilik lama) kepada pembeli (pemilik baru). Perbuatan hukum yang memindahkan hak ini menunjukkan bahwa peralihan hak atas tanah ini berlaku selamanya juga terkait harganya (Sutedi, 2012). Proses perpindahan/ beralihnya hak atas tanah dibuktikan dengan akta yang dibuat PPAT, untuk penyerahan hak kepemilikan atas tanah, Selain tanahnya yang diserahkan secara nyata juga dilakukan penyerahan secara Yuridis (Yuridische Levering). Menrut Pasal 1 Overschrijvings Ordonantie yang dikutip Boedi Harsono (1977), bahwa syarat dari peralihan hak yang dapat digunakan sebagai pembuktian adalah pendaftaran tanah.

Berdasarkan perkembangan saat ini banyak masyarakat melakukan jual beli tanah hanya dihadapan Kepala Kecamatan/ Kepala desa yang belum ditunjuk sebagai PPAT sementara sedangkan masyarakat melakukan jual beli, padahal dalam ketentuan diatas sudah dijelaskan jual beli sah bila dihadapan PPAT. Melihat kasus tersebut apakah jual beli tersebut sah menurut hukum, menurut Boedi Harsono itu dianggap "sah" jadi hak miliknya berindah dari penjual kepada pembeli, asalkan jual beli tersebut memenuhi syarat-syarat materiil (baik mengenai penjual, pembeli maupun tanahnya) (Sutedi, 2012).Kasus hukum selanjutnya juga terjadi jika bagaimana dengan pembeli ketika melakukan pendaftaran tidak mempunyai cukup alat bukti be- 
rupa akta, kemungkinan dari hal ini pembeli akan mengalami kesulitan dimana kantor Badan Pertanahan Nasional setempat tidak akan menerimanya.

Melihat kasus masyarakat saat ini sangat diperlukan peran dari BPN untuk terjun aktif dalam memberikan pelayanan pendaftaran dan penerbitan akta tanah kepada masyarakat sehingga perlindungan hak-hak masyarakat dalam memperoleh kepastian hukum kepemilikan tanahnya terjamin. Berkaitan dengan keabshan akta tanah tergantung bagaimana kebijakan PPAT setempat dan hal yang terpenting adalah pembuatan akta jual beli tidak boleh dilakukan oleh PPAT dari luar wilayah kerja PPAT setempat.

\section{Faktor Penghibahan Tanah yang Cacat Hukum}

Hibah merupakan suatu pemberian benda oleh seseorangkepada pihak lain tanpa ada kontraprestasi dari pihak yang diberi. Dilakukan secara suka rela pada waktu sipemberi hibah masih hidup. Berbeda dengan warisan yang beralihnya hak kepemilikan terjadi setelah pemberi meninggal dunia.

Keabsahan akta waris sebelum adanya Peraturan Pemerintah Republik Indonesia Nomor 24 Tahun 1997 masih tunduk dalam peraturan yang diatur dalam KUHPerdata dimana surat hibah wasiat harus dihadapan notaris, apabila tidak dilakukan maka surat hibahnya tidak memiliki kekuatan hukum. Pengecualian KUHPerdata bagi mereka yang tunduk terhadap pengaturan surat hibah hukum adat, surat hibah dilakukan dibawah tangan hanya proses di kantor Pertanahan harus dibuat dengan Akta PPAT agar hibah atau wasiat itu aman sebaiknya didaftarkan peralihan haknya di kantor Pertanahan.(Sutedi, 2012)

Proses pendaftaran dan pemberian hak kepemilikan atas tanah bagi pemberi hibah kepada ahli waris dan penerima hibah tergantung kepada informasi yang ada dalam akta hibah tanah. Hal ini berarti bahwa PPAT merupakan pihak yang bertanggungjawab terhadap kebernaran dan kepastian isi akta hibah dan menyampaikannya kepada kantor BPN setempat.

\section{Faktor Pewarisan Tanah yang Cacat Hukum}

Menurut Pasal 26 UUPA, perolehan hak milik terjadi karena pewarisan dari pemilik kepada ahli warisnya. Apabila warisannya jatuh ke para ahli warisnya, namun ternayata tanah tersebut satu-satunya maka terjadilah kepemilikan bersama. Apabila pewaris sebelum meninggal telah membagi warisannya dan membuat surat wasiat, maka tanah tersebut menjadi kepemilikan masing-masing ahli waris berdasarkan wasiat. Sebagai dasar untuk pembuktian surat keterangan wasiat ini penting untuk mendaftarkan tanah ahli waris. Perkembangan masyarakat dewasa ini, untuk memperoleh surat keterangan waris tidak dapat sepenuhnya sama secara nasional pengaturan tadi karena hukum waris masyarakat di Indonesia masih berbeda-beda.

Pembagian hak waris diatas adalah sesuai ketentuan Pasal 51, dimana pembagian hak tanah warisan bersama dibagi menjadi masing-masing pemegang hak diatur berdasarkan kesepakatan serta didaftarkan untuk mendapatkan akta PPAT. Seringkali terjadi di masyarakat sengketa dalam warisan dengan bermacam-macam kasus, misalkan tanah diwariskan kepada salah satu pihak namun pihak lain telah mendapatkan tanah sebelumnya dan mendapatkan sertifikat walaupun bukan pewaris sah obyek yang disengketakan juga sering terjadi sertifikat ganda.

\section{Faktor Pewakafan Tanah yang Cacat Hukum}

Perkembangan masyarakat dewasa ini sering terjadi praktek sebidang tanah yang diwakafkan namun dilakukan suatu transaksi (jual beli, sewa beli, hibah, waris, penjaminan dan bentuk peng- 
alihan hak lainnya) di masyarakat, hal tersebut merupakan bentuk faktor pewakafan yang cacat hukum. Di masyarakat sering terjadi bahwa tanah yang sudah diwakafkan untuk kepentingan agama dan sosial namun beberapa tahun kemudian muncul tuntutan dari ahli warisnya yang mengklaim apa yang telah dilakukan orang tuanya(pewaris) yang mewakafkan tanah tersebut tidak sah. Ahli warisnya tersebut berusaha minta kembali tanah yang sudah diwakafkan itu melalui Pengadilan.

Menurut Wiwin Ima Shofa (2008), faktorFaktor penyebab tanah wakaf belum didaftarkan, adalahKurangnya pemahaman terhadap berbagai peraturan tata cara/prosedur pendaftaran tanah; sebagian surat-surat bukti hak tentang tanah itu tidak ada lagi; Kurangnya tenaga khusus untuk menekuni pendaftaran tanah.Adanya anggapan sementara bahwa tanpa sertifikatpun kedudukan tanah cukup kuat atau kepastian hukumnya terjamin; Biaya pengurusan dan pendaftaran tanah.

Di Indonesia jumlah aset tanah wakaf belum diketahui pasti secara akurat karena data-data tentang tanah wakaf di Indonesia tidak terkoordinir dengan baik dan terpusat di institusi yang professional. Kemidian tanah wakaf tidak dikelola untuk hal-hal yang produktif, yang bisa menjadi instrument yang kontributif bagi upaya peningkatan kualitas hidup umat Islam dan umat manusia. Selain penggunaan tanah wakaf yang tidak dikelola dengan baik, juga banyak tanah wakafyang tidak dan belum bersertifikat sehingga sering menjadi obyek sengketa bahkan oleh orang tidak bertanggungjawab diperjual belikan secara melawan hukum (Sutedi, 2012).

\section{Simpulan}

Peralihan hak atas tanah wajib untuk didaftarkan. Peralihan hakatas tanah ini meliputi jual beli tanah, penghibahan tanah, pewarisan tanah dan perwakafan tanah. Hak atas tanah beralihdari penjual ke pembeli, dari penghibah ke yang menerima hibah, dari pewaris ke ahli waris dan dari orang yang mewakafkan ke nadzir. Peralihan hak ini harus dibuatkan Akta PPAT/ PPAIW sesuai dengan PP No. 24 Tahun 1997. Dengan memiliki akta mereka wajib untuk mendaftarkan ke BPN guna mendapatkan kepastian hukum dan perlindungan hukum sebagai pemegang hak dengan bukti berupa Sertifikat.

Adakalanya peralihan hak ini cacat hukum Akta PPAT tidak ada/ tidak dibuat, maka peralihan hak itu tidak sah menurut hukum, karena tanpa Akta PPAT/PPAIW tidak bisa didaftarkan ke BPN. BPN tidak bisa menerima pendaftaran tanah yang tanpa disertai Akta PPAT/PPAIW sebagai salah satu syarat yang utama, berarti sertifikat juga tidak akan terbit. Kalau ternyata sertifikat tanah bisa terbit harus dilihat apakah itu sertifikat benar-benar asli atau palsu.Apabila ternyata sertifikat itu palsuatau sertifikat ganda, maka penanganannya harus di melihat kembali ke BPN dan bagaimana langkah selanjutnya tergantung jawaban BPN.

\section{DAFTAR PUSTAKA}

Anwar,Moh. Muamalat. 1992. Munakahat, Faraid dan Jinayat, Sudarsono, Pokok-Pokok Hukum Islam. Cetakan Pertama. Rineka Cipta. Jakarta.

Badan Pertanahan Nasional. 1989. Himpunan Karya Tulis Pendaftaran Tanah. Jakarta.

Badan Pertanahan Nasional. 1997.Hukum Agraria Indonesia: Sejarah Pembentukan Undang-Undang Pokok Agraria, Isi dan Pelaksanaanya. Jilid ICetakan ketujuh. Djambatan. Jakarta.

Daliyo, J.B.\& Kawan-kawan. 2001.Hukum Agraria I. Cetakan 5. Prehallindo. Jakarta. 2001.

Effendi,Bachtiar. 1993. Kumpulan Tulisan Tentang Hukum Tanah. Alumni. Bandung.

Harmon. 2010. Pendaftaran Pemindahan Hak Atas Tanah Dengan Akta PPAT Yang Dibuat Sebelum Berlakunya PP No. 24 Tahun 1997 Di Kantor Pertanahan Jakarta Pusat. Tesis. Program Studi Magister Kenotariatan Program Pascasarjana Universitas Diponegoro. Semarang. 


\section{Jurnal Cakrawala Hukum}

Vol.8, No.1 Juni 2017: 118-128

Harsono,Boedi.1999. Hukum Agraria Indonesia: Sejarah Pembentukan Undang-Undang Pokok Agraria, Isi dan Pelaksanaannya. Jilid 1, HukumTanah Nasional. Edisi Revisi. Djambatan. Jakarta.

Harsono,Boedi.2002. Menuju Penyempurnaan Hukum Tanah Nasional.Cetakan I. Universitas Trisakti. Jakarta.

Lubis, M. Yamin \& Abd. Rohim Lubis.2012. Hukum Pendaftaran Tanah,Peraturan Pemerintah Republik Indonesia Nomor 13 Tahun 2010 Sebagai Jenis dan Tarif Atas Jenis Penerimaan Negara Bukan Pajak yang Berlaku pada Badan Pertanahan Nasional.Mandar Maju. Bandung.

Parangin,Effendi, 1991.Hukum Agraria di Indonesia, Suatu Telaah dari SudutPandang Praktisi Hukum. Rajawali Pers. Jakarta.

Parangin,Effendi. 1994.Praktek Jual Beli Tanah, Raja Grafindo Persada. Jakarta.

Parlindungan,A.P.1999. Pendaftaran Tanah di Indonesia (Berdasarkan PP24Tahun 1997) Dilengkapi Dengan Peraturan Jabatan Pejabat Pembuat Akta Tanah (PP37 Tahun 1998). Mandar Maju. Bandung.
Peraturan Pemerintah Republik Indonesia Nomor 10 Tahun 1961 Tentang Pendaftaran Tanah. Jakarta.

Peraturan Pemerintah Republik Indonesia Nomor 24 Tahun 1997 Tentang Pendaftaran Tanah. Jakarta.

Shofa, Wiwin Ima. 2008. Status Kekuatan Hukum Tanah Wakaf Tanpa Sertifikat (Studi Kasus di Desa Lumbang Rejo, Kec. Prigen, Kab. Pasuruan). Skripsi. Fakultas Syari'ah Universitas Islam Negeri Maulana Malik Ibrahim. Malang.

Sutedi, Adrian.2007. Peralihan Hak Atas Tanah dan Pendaftarannya. SinarGrafika. Jakarta.

Sutedi,Adrian.2012. Sertifikat Hak Atas Tanah. Sinar Grafika. Jakarta. 2012.

Undang-Undang Republik Indonesia Nomor 5 Tahun 1960 tentang Peraturan Dasar Pokok-Pokok Agraria. Jakarta.

\section{How to Cite:}

Susilaningsih, Tri. 2017. Terbitnya Sertifikat Hak Atas Tanah Akibat Peralihan Hak yang Cacat Hukum. Jurnal Cakrawala Hukum. 8 (1): 118-128. 